\author{
Wojciech Błażejewski \\ Zakład Metodologii Badań Pedagogicznych \\ Uniwersytet Rzeszowski
}

\title{
Funkcjonowanie systemu oświaty w okresie cywilizacji informacyjnej
}

W opiniach licznych specjalistów spotkać można ocenę, iż Polska na przełomie XX i XXI wieku znalazła się w sytuacji, w jakiej zachodnie społeczeństwa były 100 lat wcześniej. Jesteśmy zatem świadkami zmian społecznych wynikających z odchodzenia od modelu społeczeństwa przemysłowego i zbliżania się ku zupełnie nowej cywilizacji naukowoinformacyjnej.

Symptomy rewolucyjnych przemian życia ekonomicznego, politycznego i społecznego na świecie, obejmujących coraz mocniej nasz kraj, to:

- szybki rozwój technologii informatycznej; staje się ona szybsza w działaniu, tańsza, łatwo dostępna, wielostronna i przyjazna użytkownikowi;

- globalizacja produkcji (towarów i usług), finansów, rynków, oczekiwań, zwłaszcza tych, którzy nic nie mają;

- nowe wyzwania dotyczące roli i suwerenności państw narodowych, zacieśniające się więzi między strukturami krajowymi a międzynarodowymi;

- fala innowacji i przedsiębiorczości w skali światowej po przezwyciężeniu tradycyjnych barier czasu, granic, a nawet języka.

Powszechnie zatem uważa się, iż w cywilizacji informacyjnej, która współcześnie powstaje, nie wystarcza już ziemia, bogactwa naturalne ani nawet kapitał, by państwo mogło dobrze prosperować (por. R. Pachociński, 1999, s. 7).

Teoretycy społeczeństwa informacyjnego są przekonani, że:

- nastąpi podniesienie roli i znaczenia wiedzy w wykonywaniu pracy, ponieważ nowa technologia wiązać się będzie ze zwiększeniem umiejętności w wykonywaniu pracy;

- powstanie wiele nowych stanowisk pracy w ramach sektora wiedzy. Liczba pracowników działów informacji naukowo-technicznej będzie wzrastać w całej gospodarce. Zakłada się, że pracownicy ci będą bardziej wykształceni niż pracownicy tradycyjnych bibliotek. Będą mieli więcej wiedzy. To właśnie oni będą odgrywać podstawową rolę w gospodarce informacyjnej (por. R. Pachociński,1999, s. 17)

Prawie od 100 lat daje się zauważyć postępujący proces globalizacji i internacjonalizacji. Ostatnio coraz częściej w ocenie zmian kulturowych na planecie, pada określenie planetyzm. Globalizacja, to nic innego jak wielostronne powiazania przekraczajace granice państw narodowych, społeczeństw we współczesnym świecie. Gospodarka globalna, to przedsiębiorstwa i przepływ kapitałów, ale również struktura regionalna, w której stare, narodowe instytucje i ponadnarodowe struktury nadal odgrywają znaczną rolę w organizacji współzawodnictwa gospodarczego w celu osiągania korzyści.

Planetyzm, określany też jako Kultura Kosmiczna, w której ludzie przeniosą stopniowo swą lojalność wobec wioski, miasta, kraju, narodu na całą planetę, będą cechowały:

- niezależność - współzależność 
- demokracja

- ochrona przyrody

- $\quad$ stałe style życia i zachowania

- równość płci

- interkulturalna i interreligijna tolerancja

- rozwiązywanie konfliktów przez negocjacje

- poleganie na polityce bezpieczeństwa.

Dla oświaty idee planetyzmu, to:

- uczenie się przez całe życie;

- uczenie inicjowane przez ucznia;

- podejmowanie uczenia się, gdy jest ono niezbędne do poprawnego funkcjonowania $\mathrm{w}$ życiu;

- uczenie modułowe zgodnie z różnymi stylami myślenia i uczenia się;

- transformacyjne uczenie się $\mathrm{w}$ wyniku zmian systemu wierzeń i zachowań - zgodnie $\mathrm{z}$ wymaganiami związanymi z codziennym życiem zawodowym i społecznym;

- uczenie się na zasadach współpracy, by lepiej przygotować się do współdziałania z innymi ludźmi (por. R. Pachociński, 1999, s. 37-38).

W kontekście dokonujących się na naszych oczach zmian cywilizacyjnych, pytać możemy o to, jakimi zmianami restrukturyzacyjnymi powinniśmy objąć tradycyjne polskie szkoły, aby mogły one przygotowywać dzieci i młodzież do tego, by były chętne do zdobywania nowoczesnej wiedzy, by chciały ze sobą harmonijnie współpracować, interesować się ludzkimi i światowymi problemami.

Pytać powinniśmy także o to, czy w niedalekiej już przyszłości czytanie, liczenie i pisanie będą nadal nieodzownymi człowiekowi umiejętnościami? Niektórzy autorzy sądzą, że będą nimi wkrótce: etyka, estetyka, umiejętność konwersacji i ekspresji, współdziałania i współpracy w zespole.

Coraz częściej i my, i młodzież, mamy wątpliwości czy rzeczywiście to treści programów nauczania, w które aktualnie wyposażamy uczniów, będą miały już w najbliższej przyszłości jakieś istotniejsze dla nich znaczenie. Te szkoły, które wszyscy znamy, przygotowują bowiem do funkcjonowania $\mathrm{w}$ społeczeństwie, które przecież odchodzi. Wiedza $\mathrm{i}$ umiejętności zdobywane w niej coraz częściej okazują się mniej przydatne na progu XXI wieku. Stwierdza to wielu badaczy (R. Pachociński, 1999, s. 122-123):

(...) Współczesne programy nauczania nie przygotowuja do życia $w$ cywilizacji informacyjnej. Obecnie można zakładać, że zdobycie wysokich umiejętności intelektualnych może dotyczyć tylko niewielkiego odsetka uczniów, natomiast oświata masowa spetniać będzie przede wszystkim funkcje spoleczne. Oświata zawsze i wszędzie stużyła politycznym i ekonomicznym celom spoleczeństwa, takim jak utrwalenie roli religii, historii, sztuki, wojskowości, integracji społecznej. Umiejętności społeczne zawsze byly ważnym skladnikiem oświaty. Rozwój oświaty powszechnej służyt celom uprzemysłowienia. Szkoła realizowata również funkcję dyscyplinująca wobec mtodego pokolenia, która schodzi obecnie na dalszy plan.

(...) Wraz z postępująca złożonościa życia i pracy będa zacierać się różnice między nauka $w$ szkole i poza szkoła. Czlowiek będzie musiat radzić sobie z wieloma istniejacymi opcjami prawie $w$ każdej sprawie, wspótpracować $z$ innymi, rozwiazywać konflikty i umiejętności takie będa miały coraz większe znaczenie. Trzeba więc je traktować jako podstawowe cele oświaty. (Wilson)

Ciagle brak jest wizji szkoły przyszłości w okresie następnego ćwierćwiecza. 25 lat to przyszłość, w która jeszcze można próbować wejrzeć, chociaż wizja taka nie może być ani zbyt dokładna, ani szczegółowa. Można jedynie próbować przedstawić różne prawdopodobne scenariusze osadzone $w$ nurcie myślenia perspektywicznego o przyszłości, niekoniecznie mając na celu samo przewidywanie, ale bardziej ksztattowanie tego, co może nastapić w przyszłości (...) 
Zmieniający się świat $i$ wzrastajace znaczenie nauki dla dalszego jego rozwoju powoduja, że wyzwaniom nadchodzacego XXI wieku może sprostać tylko człowiek wielostronnie wyksztatcony, zdolny do myślenia $w$ kategoriach innowacyjnych $i$ alternatywnych, energiczny, sprawny, wrażliwy na wartości, uznający je za dyrektywy postępowania, drogowskazy życia, czyli ,człowiek petny”(K. Denek).

\section{PRZEJAWY POWSZECHNEGO KRYZYSU SZKOEY}

Powszechnie zauważany i odczuwany kryzys wartości i wzorców osobowościowych, będący - jak wspomniano - konsekwencją m.in. procesów globalizacji i różnicowania się kultury, nie pozostaje bez wpływu na funkcjonalność tradycyjnych nie reformowanych od lat systemów kształcenia w Polsce i na świecie.

I. Illich sądzi, że kryzys obecnej szkoły przejawia się w:

- reprodukowaniu przez nią istniejących struktur społecznych i ekonomicznych,

- dysproporcji między kosztami i efektami jej pracy,

- traktowaniu nauczania jako towaru, a nie środka rozwoju człowieka,

- fetyszyzacji dyplomów,

- dyskryminowaniu dzieci i młodzieży z uboższych warstw ludności,

- tłumieniu inicjatywy i naturalnej aktywności uczniów,

- autorytaryzmie,

- niezdrowej rywalizacji,

- konformizmie,

- szerzeniu przekonania, że wykształcenie można zdobyć tylko w murach szkoły,

- stosowaniu przez nauczycieli awersyjnych bodźców wobec wychowanków,

- ignorowaniu różnic indywidualnych,

- braku przystosowania do potrzeb współczesności (por. Cz. Kupisiewicz 1985, s. 30)

\section{PODSTAWOWE PROBLEMY WSPÓlCZESNEJ EDUKACJI W KRAJACH UNII EUROPEJSKIEJ ORAZ DOKUMENTY UKAZUJACE STAN I TENDENCJE EDUKACYJNE KOŃCA XX WIEKU}

Podstawowe problemy współczesnej edukacji krajów Unii Europejskiej w znacznej mierze są podobne do wyzwań, jakie aktualnie napotyka nasz kraj. Znalazły one odbicie w dokumencie opracowanym w 1995 roku przez Komisję Europejską, tzw. Białej Księdze pt. Nauczanie i uczenie się. Na drodze do uczacego się społeczeństwa (Warszawa 1997).

Według W. Rabczuka (1997), autorzy Białej Księgi nie pretendowali do wyczerpującej analizy wspólnotowej problematyki edukacyjnej. Skoncentrowali się na ukazaniu nowych wyzwań, jakie stają przed polityką edukacyjną Unii Europejskiej i jej państw członkowskich u progu XXI wieku. Intencją Białej Księgi było zapoczątkowanie, w obliczu głębokich przemian współczesnych społeczeństw, rozległej debaty na temat możliwości przyspieszenia wkroczenia państw Unii Europejskiej na ścieżkę społeczeństwa kognitywnego. Biała Księga, podobnie jak Raport J. Delorsa, upatruje siły sprawcze zachodzących współcześnie transformacji społeczeństw w zjawiskach globalizacji, tworzenia się społeczeństw informatycznych oraz rewolucji naukowo-technicznej. Rezultatem tworzenia się społeczeństwa informatycznego jest zmiana istoty pracy i organizacji produkcji. Praca o charakterze rutynowym i iteratywnym, którą wykonywała większość pracowników najemnych, zastępowana jest obecnie działalnością bardziej samodzielną. Sytuacja ta zwiększa wprawdzie rolę czynnika ludzkiego, lecz jednocześnie pracownik staje się w większym stopniu uzależniony od zmian w organizacji pracy. Stąd konieczność nie tylko przystosowywania się do nowych materialnych warunków pracy, lecz również do jej zmieniających się form (W. Rabczuk 1997, s. 71-75). 
Władze oświatowe wielu krajów, stając wobec jakościowo innych oczekiwań społecznych wywoływanych coraz szybszym rozwojem cywilizacji w drugiej połowie XX wieku, podjęły zakrojone na szeroką skalę analizy i ocenę aktualnego stanu edukacji.

W Polsce dokonano tego dwukrotnie: w latach 1971-1973 Komitet Ekspertów dla opracowania Raportu o Stanie Oświaty w PRL (przewodniczył mu socjolog - profesor Jan Szczepański) oraz w latach 1987-1989 Komitet Ekspertów do Spraw Edukacji Narodowej (przewodniczył mu pedagog - profesor Czesław Kupisiewicz). Wynikiem studiów, prac i analiz stały się dwa podstawowe raporty: Raport o stanie oświaty w PRL (1973) i Edukacja narodowym priorytetem. Raport o stanie i kierunkach rozwoju edukacji narodowej w Polskiej Rzeczypospolitej Ludowej (1989). Na rzeczywistość szkolną i oświatową w naszym kraju raporty te nie wywarły głębszego wpływu (por. S. Wołoszyn 1997, s. 65).

Efektem prac badawczych stały się dokumenty ukazujące stan i tendencje edukacyjne końca wieku oraz wizje edukacji przyszłości. Jednym z nich był Raport Klubu Rzymskiego z roku 1979. Został on przełożony na język polski i odpowiednio skomentowany (por. E. Faure i in. 1975; 1979; J. W. Botkin i in. 1982; 1987). Analizy tych raportów i raportów różnych krajów na ogólniejszym tle współczesnych tendencji reformistycznych dokonał w Polsce m.in. Czesław Kupisiewicz (1978; 1982; 1985) (por. S. Wołoszyn 1997, s. 65).

Wspomniane dokumenty, eksponujące obszary dysfunkcjonalności aktualnego systemu, wskazywały nową wizję edukacji jutra. Celem jej jest zaktywizowanie ludzi, poszerzenie zakresu ich odpowiedzialności za bieg spraw pozajednostkowych, ukazanie im nowych horyzontów, twórcze spożytkowanie ich możliwości (...) (Cz. Kupisiewicz 1985, s. 198), i co najważniejsze, wdrożenie do uczenia się z przyszłości, a nie tylko - jak głównie dotąd z przeszłości (por. Cz. Kupisiewicz 1985 s. 179-243).

Nad wizją edukacji przyszłości zastanawiają się także autorzy raportów amerykańskich (Naród w obliczu zagrożenia: imperatyw reformy edukacji - 1983; Propozycje Grupy Paideia - 1982; Przysposobić Amerykanów do życia w XXI wieku - 1983; Edukacja w USA1988), japońskich (raport Narodowej Rady ds. Reformy Edukacji - 1984), chińskich (raporty $z$ lat 1973 - 1989) i polskich (raport o stanie i kierunkach rozwoju edukacji narodowej w Polskiej Rzeczpospolitej Ludowej - 1989).

Państwa Piętnastki starają się również sprostać edukacyjnym wyzwaniom XXI wieku. Pierwszą próbą prezentacji prognoz rozwoju oświaty dla krajów Unii Europejskiej był raport Jensena, opublikowany w 1972 roku w Hadze, pt. Perspektywy oświaty $i$ wychowania $w$ Europie Zachodniej. Projekt I: Kształcenie na potrzeby 21 stulecia. Autorzy raportu zwrócili szczególną uwagę na fakt, iż analizę procesów edukacyjnych należy rozpatrywać w ścisłym powiązaniu ze zjawiskami ekonomicznymi, społecznymi i kulturowymi, determinowanymi z kolei przez sytuację polityczną o zasięgu światowym, europejskim i wewnętrznym każdego kraju. Potwierdzeniem uwag zawartych w raporcie Jensena są dokumenty oświatowe opracowane w latach osiemdziesiątych przez kraje członkowskie UE. Wśród nich na szczególną uwagę zasługują niemieckie założenia Realnej utopii edukacyjnej; francuski raport oświatowy pt. Edukacja a spoleczeństwo, Wyzwania roku 2000 oraz brytyjski program rozwoju oświaty pt. Uczyć i uczyć się: ku społeczeństwu kognitywnemu znany pod nazwą Białej Księgi. Wszystkie te dokumenty wykazują dążenie do rozszerzenia powszechności zinstytucjonalizowanego wychowania przedszkolnego i szkoły średniej drugiego stopnia oraz polepszenia jakości pracy dydaktyczno-wychowawczej, a tym samym zmniejszenia odpadu i odsiewu szkolnego (por. D. Dziewulak 1997, s. 131-132).

Z inspiracji UNESCO powstało już wcześniej wiele raportów na temat stanu edukacji w świecie. Najbardziej znane, to Światowy kryzys edukacji - analiza systemów Philipa H. Coombsa (1968) i Uczyć się, aby być Edgara Faure'a (1972). W roku 1993 powstała Międzynarodowa Komisja do spraw Edukacji dla XXI wieku. Na jej przewodniczącego powołano Jacquesa Delorsa. W skład Komisji weszło 14 osobistości reprezentujących wszystkie 
regiony świata ${ }^{(*)}$. Zdaniem J. Delorsa, charakterystyczne zjawiska determinujące przyszłość, to między innymi:

- Globalizacja, której nie wolno ignorować i z która każdy musi się liczyć. Wszyscy stajemy się mieszkańcami planetarnej wioski świata, którym rządza wszechogarniajace prawa wspótzależności.

- Ewolucja stosunków Pótnoc - Potudnie, która czyni nieadekwatna dotychczasowa dychotomię, na skutek akceleracji rozwoju krajów Pacyfiku.

- Koniec zimnej wojny. Wszystkie kraje odczuly jego skutki, gdyz ideologie przeciwstawnych bloków rozprzestrzenity się na cały świat. Erozji uległy dominujące narracje, pozostawiajac po sobie ideologiczna próżnię.

- Rosnace znaczenie środków przekazu informacji i komunikowania się.

- Szybki postęp wiedzy, transformacje społeczeństw i ich nierównomierny rozwój, aspiracje jednostek oraz witalne potrzeby międzynarodowego zrozumienia i pokoju ukierunkowaty refleksję autorów raportu i nadaty ich wizji edukacji szerszy wymiar (za: W. Rabczuk 1997, s. 58).

Konkluzje i zalecenia Komisji były między innymi następujące: edukacja powinna przyczyniać się do zwalczania ubóstwa, ostracyzmu społecznego, przemocy, wojen, współtworzyć lepszy świat, w którym szanuje się prawa człowieka i panuje wzajemne zrozumienie, a postęp wiedzy wykorzystywany jest dla dobra wszystkich narodów. Autorzy badań apelują o zwaloryzowanie aspektów etycznych i kulturalnych edukacji, której podstawowym zadaniem staje się poszukiwanie sposobu przekształcania faktycznej współzależności ludzi w ich świadomą solidarność. Postulat budowania świata bardziej solidarnego autorzy raportu określają mianem nowego humanizmu. Agresywne nacjonalizmy powinny ustąpić miejsca uniwersalizmowi, przesądy kulturalne i etniczne - tolerancji i pluralizmowi, totalitaryzm demokracji, świat zaś podzielony pod względem dostępu do nowoczesnych technologii, światem technologicznie zjednoczonym (tamże, s. 59-60).

Szczególne znaczenie, przypisują oni edukacji (w tym ustawicznej), która ich zdaniem winna oprzeć się na czterech filarach:

1. Uczyć się, aby żyć wspólnie.

2. Uczyć się, aby wiedzieć.

3. Uczyć się, aby działać.

4. Uczyć się, aby być (por. W. Grabczuk, 1997).

Stanowisko to pokrywa się z opinią E. Faure'a: rozwój ma na celu pelny rozkwit człowieka, $w$ całym bogactwie jego osobowości $i$ w różnorodnych formach ekspresji $i$ zaangażowania: jako jednostki, czlonka rodziny i społeczeństwa, obywatela i producenta, wynalazcy techniki i twórcy marzeń (E. Faure, 1975, s. 15).

Komisja UNESCO konsekwentnie potwierdziła także doniosłe znaczenie formalnej edukacji podstawowej. Każda osoba - dziecko, młodzieniec lub dorosty - powinna korzystać $z$ ksztatcenia dostosowanego do jej fundamentalnych potrzeb edukacyjnych. Potrzeby te dotycza w równym stopniu zasadniczych narzędzi uczenia się (czytanie, pisanie, komunikowanie się, rachunki, rozwiazywanie problemów), jak i fundamentalnych treści edukacyjnych (wiadomości, umiejętności, wartości, postawy), których czlowiek potrzebuje do przetrwania, do rozwijania wszystkich swych zdolności, do godnego życia i pracy, do petnego uczestnictwa w rozwoju, do poprawy swej egzystencji, do podejmowania rozsadnych decyzji, do kontynuowania nauki. (Artykuł 1-1 - Swiatowa deklaracja na temat edukacji dla wszystkich. Wytyczne dotyczace zaspokajania fundamentalnych potrzeb edukacyjnych, 1990).

\footnotetext{
${ }^{(*)}$ Polskę reprezentował Bronisław Geremek, historyk, poseł na Sejm RP, Minister Spraw Zagranicznych - działacz polityczny.
} 


\section{ZNAMIONA KRYZYSU POLSKIEJ EDUKACJI}

Przemiany społeczno-gospodarcze, jakie nastąpiły w ostatnich latach w Polsce, ukazały z całą wyrazistością niską efektywność zewnętrzną i wewnętrzną funkcjonującego systemu oświaty.

Nasza dziewiętnastowieczna szkoła zanudza dzieci i młodzież oraz hamuje rozwój większości z nich, nie umie zaadaptować się do tempa i zakresu zmian jej otoczenia, nie mówią już o tym, że nie jest zdolna przygotowywać do rewolucyjnych zmian technologicznych, ekonomicznych, kulturowych i społecznych w najbliższej przyszłości. Dorosłe społeczeństwo jest źle wykształcone: tak co do poziomu, jak i sztywnych specjalizacji, i mato elastycznych form myślenia.

Rozległe obszary ciemnoty $i$ demoralizacji społecznej oraz zmurszała $w$ swych treściach i funkcjach szkoła współczynia z Polski społeczeństwo antywychowujace, z zagubionym elementarnym instynktem samozachowawczym, który normalnie nakazuje troszczyć się o maksymalny rozwój własnych dzieci (Z. Kwieciński, 1999, s. 31).

Znamionami powstałego kryzysu oświaty według Cz. Kupisiewicza (1995) są między innymi następujące wskaźniki:

- $43 \%$ absolwentów szkół podstawowych kontynuuje naukę w maturalnych szkołach średnich;

- $\quad 10 \%$ młodzieży dziewiętnastoletniej rekrutuje się do szkół wyższych;

- $80 \%$ studentów wywodzi się z liceów ogólnokształcących;

- $\quad 10 \%$ uczniów szkół podstawowych uczy się dłużej niż 8 lat.

Jednocześnie przeprowadzone badania wykazywały spadek poziomu podstawowych umiejętności, takich jak: czytanie, ortografia, operacje arytmetyczne, ubożenie zasobu słownictwa oraz znaczne luki w operatywnych wiadomościach z różnych przedmiotów. Towarzyszy temu niski przeciętnie poziom uzyskiwanych przez szkołę wyników nauczania i wychowania. Wśród przyczyn tego stanu wymienia się: niezgodność treści edukacji, metod, a także organizacji pracy dydaktyczno-wychowawczej, z coraz wyraźniej formułowanymi wymaganiami teraźniejszości i przyszłości (por. Cz. Kupisiewicz 1995a, s. 111-113).

W ocenie J. Wilsz (1996/1997) przejawami dysfunkcjonalności szkoły - w odniesieniu do uczniów - są:

- bierność postaw i apatia,

- brak aktywności, krytycyzmu, samodzielności sądów,

- nieumiejętność rozwiązywania rzeczywistych multidyscyplinarnych problemów,

- konflikty w stosunkach uczeń - nauczyciel,

- brak umiejętności myślenia problemowego oraz dyskutowania, argumentowania, polemizowania,

- bezradność absolwentów na rynku pracy,

- zmęczenie psychiczne prowadzące do schorzeń lub zachowań patologicznych.

Według J. Auleytnera (1999, s. 55) dwie trzecie polskiej ludności czynnej zawodowo reprezentuje:

- ograniczoną podatność na wszelkie innowacje, a nawet strach przed zmianami, jakie niesie postęp;

- słabą przyswajalność argumentacji prezentowanej przez elity gospodarcze i polityczne w przedmiocie koniecznych reform;

- nierozumienie procesów społecznych, ekonomicznych i politycznych związanych z integracją europejską;

- brak zdolności do kreowania własnego rozwoju.

W 1994 roku w ośmiu krajach, tj. Kanadzie, Stanach Zjednoczonych Ameryki, Holandii, Niemczech, Szwecji, Szwajcarii i Polsce, przeprowadzono badania alfabetyzmu funkcjonalnego na reprezentatywnych próbach 3 tysięcy osób (mężczyzn i kobiet) w wieku od 16 
do 65 lat. Alfabetyzm funkcjonalny to umiejętność przetwarzania informacji w zakresie czytania, pisania i liczenia, konieczna do korzystania w życiu codziennym i w pracy zawodowej z powszechnie spotykanych materiałów drukowanych (por. R. Mitter 1993).

We wszystkich krajach uczestniczących w badaniach, stosowano identyczne procedury i narzędzia. Wykorzystano testy edukacyjne pomyślane tak, aby mierzyły umiejętność przetwarzania informacji dotyczących przeczytanego tekstu, a także pisania i liczenia. Wyniki pomiaru wyrażano przez przypisanie wszystkim respondentom miejsc na jednym z pięciu poziomów trzech odrębnych skal: tekstu, dokumentu i umiejętności matematycznych. Ankietowani rozwiązywali około 50 zadań. Składały się one z różnych fragmentów tekstów, np. artykułów, ulotek reklamowych, instrukcji, wykresów, tabel itd., które dobierano tak, aby wskazały umiejętność odnajdywania informacji, ich przetwarzania oraz syntezy. Proszono między innymi, np. o wypełnienie kwestionariusza osobowego, zinterpretowanie rozkładu jazdy pociągów, sprawdzenie rachunku, obliczenie odsetek do zapłacenia, objaśnienie formularza podatkowego itd. We wszystkich trzech skalach na najniższym poziomie alfabetyzmu funkcjonalnego najwięcej znalazło się Polaków - 70\%. Tylko nieliczne osoby po studiach $(16 \%)$ potrafią swobodnie czytać nieskomplikowane teksty i formułować wypływające z nich wnioski. Ze zrozumieniem prostej instrukcji ma kłopoty $64 \%$ badanych urzędników. Co dziesiąty rolnik czyta i rozumie instrukcje wskazujące na sposób stosowania nawozów sztucznych. Tylko $1 / 3$ badanych Polaków rozumie w pełni artykuł w gazecie na temat ekologicznych zagrożeń rozwoju cywilizacyjnego. Prawie 23\% respondentów nie zawsze może samodzielnie zrozumieć informacje podawane przez urzędy państwowe. Tylko $14 \%$ badanych uważa, że miewa kłopoty ze zrozumieniem instrukcji na opakowaniu lekarstwa, ale aż 85\% musi korzystać z pomocy przy wypełnieniu formularzy urzędowych. Podobnie około $75 \%$ nie potrafi na podstawie rozkładu jazdy odpowiedzieć prawidłowo na pytanie o godzinę odjazdu ostatniego autobusu w sobotę wieczorem. Kilkanaście procent osób z wyższym wykształceniem, w tym $1 / 5$ menedżerów i specjalistów oraz $1 / 3$ urzędników, znalazła się w omawianych wynikach badań na najniższym poziomie alfabetyzmu. Można także przyjąć, że wśród nauczycieli, dziennikarzy telewizyjnych i radiowych, autorów artykułów prasowych, urzędników itd., są osoby posiadające zaledwie elementarne kompetencje alfabetyczne. Badania wykazały, że około $95 \%$ osób źle oceniających swoje umiejętności nigdy nie korzysta z bibliotek; $96 \%$ nie chodzi do kina, teatru, ani na koncerty; $82 \%$ nie pisze listów, zaś $79,1 \%$ nigdy nie czyta książek; $80 \%$ polskich pracowników z najniższym poziomem omawianych sprawności jest przekonana, że ich umiejętności czytania i pisania nie wpływają na szanse awansu zawodowego.

Polska ma wśród porównywanych krajów najwyższy procent ludzi z wykształceniem podstawowym - 26,9\%, a zaledwie 7,2\% z wykształceniem wyższym. We wszystkich krajach, poza Polską, badani z pełnym wykształceniem średnim lokują się w większości na trzecim poziomie, natomiast $\mathrm{w}$ Polsce posiadający wykształcenie średnie interpretują informacje na poziomie o jeden stopień niższym. Uderzający jest w Polsce najwyższy, wśród badanych krajów, odsetek respondentów z wyższym wykształceniem lokujących się na najniższym poziomie alfabetyzmu, $w$ tym $w$ zadaniach testowych aż $11 \%$, w zadaniach $\mathrm{z}$ dokumentami aż 16\%. Najwięcej słabych wyników wśród tych osób widać w grupie najstarszej (53-64 lat).

W Polsce w ciągu 12 miesięcy, poprzedzających badania, dokształcało się zaledwie $15 \%$ ankietowanych, podczas gdy w pozostałych krajach wskaźnik ten wynosił $40 \%$ (por. M. Jadczak 1998/99, s. 9-10). 


\section{OCENA KONDYCJI SYSTEMU POLSKIEJ EDUKACJI W ŚWIETLE BADAŃ EKSPERTÓW KRAJO-} WYCH I OECD

W czerwcu 1995 roku odbyło się w Warszawie nadzwyczajne posiedzenie Komitetu Edukacji OECD poświęcone w całości przeglądowi polskiej polityki edukacyjnej. Przegląd został dokonany na życzenie władz polskich. OECD - Organizacja Współpracy Gospodarczej i Rozwoju (Organisation for Economic Cooperation and Development - OECD), powstała w 1961 roku z przekształcenia Organizacji Europejskiej Współpracy Gospodarczej $(O E E C)$, powołanej w 1948 roku do koordynowania powojennej odbudowy Europy w oparciu o plan Marshalla. Najważniejszym, statutowym celem OECD jest działanie na rzecz osiągnięcia przez kraje członkowskie, jak najwyższego wzrostu gospodarczego przy zachowaniu stabilności finansowej, rozwijanie międzynarodowej wymiany gospodarczej oraz promowanie podnoszenia poziomu życia ludzi. OECD skupia obecnie 29 krajów. W pracach OECD uczestniczy również Komisja Europejska.

W oparciu o materiał zebrany w czasie wizyt przygotowano raport (Review of Education Policy in Poland - Examiners' Report and Questions), który został przedstawiony i przedyskutowany na posiedzeniu Komitetu Edukacji. Raport ekspertów zawiera 5 rozdziałów poświęconych grupom zagadnień wybranych przez Ministerstwo Edukacji Narodowej, jako przedmiot przeglądu:

- Jakość i efektywność edukacji.

- Nauczyciele - status zawodowy i kształcenie.

- Szkolnictwo wyższe.

- Finansowanie edukacji, skuteczne zarządzanie.

- Rozwijanie ,zasobów ludzkich”.

Oceny zawarte w Raporcie pokrywają się w zasadzie z wynikami badań polskich ekspertów: J. Czapińskiego, I. Białeckiego i Z. Kwiecińskiego (1999). Generalnie wszyscy eksperci są zgodni co do tego, że nasze społeczeństwo jest źle wykształcone. Przez wiele lat niskie limity przyjęć do liceów ogólnokształcacych przyniosty skumulowany efekt $w$ postaci jednego z najniższych wskaźników skolaryzacji $w$ świecie $w$ zakresie poziomu przyjęć do liceów i liczby osób ze średnim wykształceniem ogólnym $i-w$ rezultacie $-z$ wyksztatceniem wyższym. Stopa wzrostu liczby uczniów średnich szkót ogólnoksztatcąych w ostatnich dziesięcioleciach $-w$ tym $w$ latach dziewięćdziesiatych - znowu stawia nas przy końcu państw cywilizowanych. Szkoty podstawowe opuszcza wciaż 15-20\% analfabetów funkcjonalnych i około 20-25\% półanalfabetów. (...) Trzy czwarte dorostych Polaków nie rozumie prostych tekstów w języku ojczystym. (...) Pod względem liczby funkcjonalnych analfabetów przodujemy w Europie. Instytucje powszechnego ksztatcenia przez dziesiątki lat petnity i nadal petnia funkcje odtwarzania nędzy kulturowej $i$ wykluczania z kultury dzieci (Z. Kwieciński 1999, s. 24).

Kwestią szeroko omówioną w raporcie jest kształcenie nauczycieli i ich nabór do zawodu. Eksperci krytykują system kształcenia nauczycieli oparty głównie o studia magisterskie, dające kwalifikacje do uczenia tylko jednego przedmiotu, nie rozwijające umiejętności praktycznych, niezbędnych do elastycznej i efektywnej pracy w szkole.

Warunkiem koniecznym powodzenia reformy jest wykształcenie i doskonalenie nauczycieli o nowych, innych niż dotychczas kompetencjach: w sensie treści - bardziej łacznych niż wąsko specjalistycznych, bardziej otwartych niż zamkniętych, bardziej twórczych niż odtwórczych, a w sensie charakteru roli zawodowej-odchodzacych od funkcji przekaziciela i egzekutora do roli przewodnika i tlumacza (Z. Kwieciński 1999, s. 32).

Powszechna świadomość i zgodność co do nowych potrzeb prowokuje cytowanego autora do zadawania dramatycznych pytań:

- Jak to zrobić w sytuacji całkowitej dowolności i wręcz pełnego chaosu w zakresie przygotowania nauczycieli w uczelniach wyższych? 
- Jak tego dokonać z tak źle do tego przygotowaną kadrą akademicką, bez nowych zasobów nowoczesnych i dostępnych podręczników i pomocy naukowych?

- Kto ma przygotować nową formację i generację nauczycieli dla zreformowanej szkoły? (por. Z. Kwieciński 1999, s. 32).

Wieloletnie, niskie nakłady publiczne na szkolnictwo wyższe, wynoszące w latach 1990/97 około 0,85\% PKB, osłabiają - zdaniem specjalistów - konkurencyjność naszej gospodarki i są „utajnioną i niedocenianą” przyczyną trudności integracyjnych Polski z Unią Europejską (por. J. Auleytner 1999).

Badania GUS-u z 1997 roku potwierdzają hipotezę o lepszych perspektywach zawodowych osób z wyższym wykształceniem, w porównaniu z innymi kategoriami bezrobotnych. Niemniej jednak w Polsce liczba osób z wyższym wykształceniem jest zbliżona do liczby osób bez żadnego wykształcenia; wykształcenia średniego, dającego dostęp do studiów wyższych przez całe życie, nie posiada $66 \%$ ludności w wieku aktywności zawodowej; brak wykształcenia wyższego i co najmniej średniego u blisko $2 / 3$ ludności w wieku aktywności zawodowej ma bezpośredni wpływ na jej ograniczone uczestnictwo w procesie pracy i w życiu społeczno-politycznym; istnieje nierówna sytuacja kobiet i mężczyzn w poziomie wykształcenia (por. J. Auleytner 1999, s. 55).

Zdaniem ekspertów, dostęp do wykształcenia wyższego tworzą bariery terytorialne oraz koszty studiów nie korespondujące $\mathrm{z}$ ubóstwem ludności. Raport wskazuje na niski prestiż kształcenia nauczycieli i badań edukacyjnych na uniwersytetach. Obawy budzi możliwość realizacji reformy, jeśli w programie studiów nauczycielskich i prac badawczych uniwersytetów nie znajdą się takie zagadnienia, jak: tworzenie programów nauczania, ocenianie, zarządzanie edukacją itp.

Zaniepokojenie ekspertów budzi fakt niewystarczających i malejących w Polsce nakładów na oświatę. Polska odziedziczyła wieloletnie skutki nakładów na oświatę mocno poniżej 4\% dochodu narodowego, poziomu uznawanego przez UNESCO za „próg śmierci oświatowej" (...) $i$ wedlug danych Banku Światowego, systematycznie obniżała wydatki na oświate, liczone jako odsetek dochodu narodowego w latach 1991-1993, aż do poziomu 2,9\%, podczas gdy inne kraje Europy Środkowej i Wschodniej, jak Czechy, Wegry, Rumunia $i$ Butgaria systematycznie podnosity te naklady, aż do przekroczenia progu $6 \%$, co jest niezbędne do rozpoczęcia reform (Z. Kwieciński 1999, s. 25).

\section{OCENA JAKOŚCI PROGRAMÓW NAUCZANIA W KONTEKŚCIE POTRZEB EDUKACYJNYCH I DOKONAŃ ROZPOCZĘTEJ REFORMY OŚWIATY}

W latach 1994 i 1995 - kiedy eksperci OECD wizytowali Polskę - ani ogólne, ani szczegółowe cele reformy oświaty nie były jasno zdefiniowane. Celom tym, jak sloganom przypisywano raczej funkcje ideologiczne niż instrumentalne. Przygotowywana była dopiero reforma programów nauczania szkolnictwa ogólnego, oparta o tzw. „minima programowe". W bardzo ograniczonym zakresie wprowadzano, nowe programy nauczania przedmiotów zawodowych (głównie w ramach realizacji programów UPET i MOVE finansowanych z funduszu bezzwrotnej pomocy Unii Europejskiej PHARE).

W opublikowanej przez UNESCO w roku 1996 pracy na temat: A Decade of reforms at compulsory education levet in the European Union (1984-96) podkreśla się, iż w reformowaniu obowiązkowego kształcenia w krajach Unii (a więc kształcenia ogólnego obejmującego na ogół szkołę podstawową i pierwszy cykl szkoły średniej) kierowano się bardzo podobnymi celami, które dadzą się ująć w 6 grup tematycznych:

- rzeczywista równość szans edukacyjnych,

- zapewnienie wszystkim obywatelom wykształcenia podstawowego,

- promowanie stabilności oraz zmiany społecznej, 
- $\quad$ przygotowanie dzieci do życia społecznego, życia w rodzinie, do pracy oraz właściwego wykorzystania czasu wolnego,

- $\quad$ wpajanie motywów do uczenia się przez całe życie oraz przygotowanie do zmian współczesnego świata,

- $\quad$ wszechstronny rozwój uczniów (A. Bogaj 1999, s. 167).

Podobieństwo $\mathrm{w}$ doborze treści w krajach UE polega na szerszym wprowadzaniu treści o charakterze interdyscyplinarnym; treści odnoszących się do obywatelskich i społecznych zachowań uczniów; treści uwzględniających tzw. europejski wymiar edukacji. Podobieństwa $\mathrm{w}$ układzie treści kształcenia znajdują wyraz przede wszystkim $\mathrm{w}$ częstym stosowaniu tzw. szerokich pól wiedzy niż tradycyjnych przedmiotów nauczania. Programy nauczania zaś są skoncentrowane na uczniu, na rozwoju jego aktywności i współpracy z innymi, na uczeniu się przez odkrywanie i działanie (por. A. Bogaj 1999, s. 168).

Cytowany autor konstatuje, że dotychczasowe polskie programy nauczania, tradycyjnie koncentrujące się na treściach odpowiadających poszczególnym dyscyplinom naukowym i na dziedzictwie kulturowym (co znajdowało odbicie w codziennej praktyce edukacyjnej, nauczycielskich kwalifikacjach, planach lekcji, wyposażeniu szkół, podręcznikach $\mathrm{i}$ materiałach dydaktycznych) nie odpowiadają kierunkom przemian $\mathrm{i}$ reform kształcenia ogólnego. Postuluje nadać tym programom charakter prospektywny, wyróżniający się w koncentracji na postawach poznawczych ucznia, jego potrzebach rozwojowych oraz wielostronnej aktywności i autokreacji.

Struktura takich programów winna być następująca:

Rys. 1. Struktura nowocześnie pojmowanego programu kształcenia

Ja

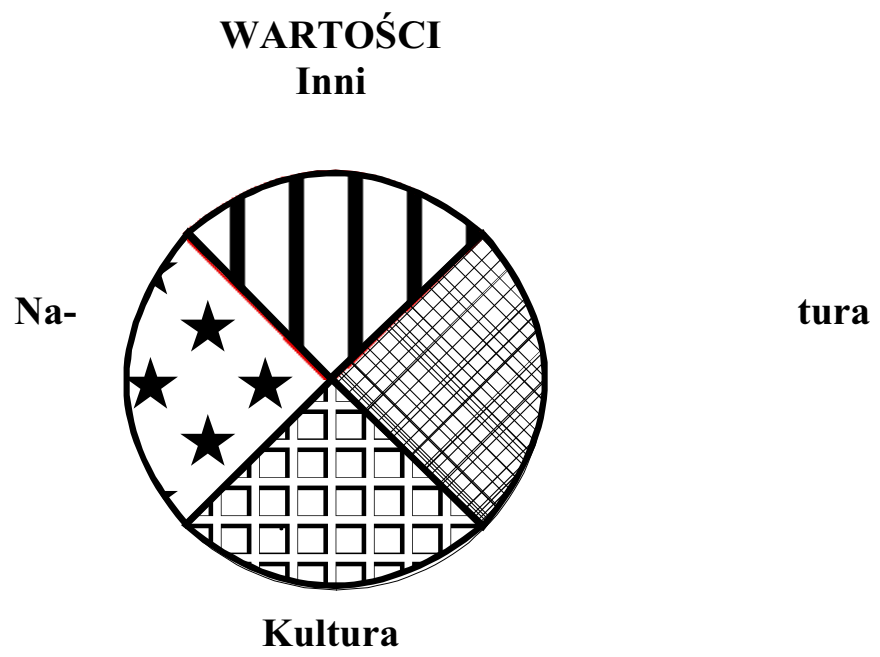

Źródło: J. Gnitecki i J. Rutkowiak (red.), Pedagogika i edukacja wobec nadziei i zagrożeń wspótczesności. Warszawa-Poznań 1999 r., s. 169

Elementy te powinny obejmować:

Natura: wprowadzenie podstawowych pojęć, praw natury, relacje czlowiek-natura;

Kultura: historia i dorobek ludzkości, rozwój kultury i jej role spoleczne oraz edukacyjne szanse i zagrożenia, ochrona dóbr;

Ja: wiedza i zrozumienie: kim jestem? Moje słabości i wady versus moje zalety, postawy wobec nauki i pracy, samorozwój, rozwój społeczny, autokreacja; 
Inni: wiedza $i$ zrozumienie tego, kim sq i jak egzystuja inni, relacje interpersonalne $w$ klasie, $w$ szkole, $w$ środowisku lokalnym, nacisk na zrozumienie innych kultur, innych religii, innych języków.

Ważne jest przy tym to, by programy byly budowane z myśla o określonym ideale wychowania, co oznacza ich orientację na określony system wartości etycznych, moralnych $i$ demokratycznych akceptowanych przez społeczeństwa (A. Bogaj 1999, s. 170).

Wśród negatywnych zjawisk obserwowanych w programach nauczania, takich jak: encyklopedyzm, historyzm, addytywizm, uniformizm, intelektualizm, akademizm treści występujących w planach i programach nauczania, szczególnie istotnych z punktu widzenia zarówno jednostki, jak i społeczeństwa, jest brak powiązania ich z życiem. Uczniowie często borykają się z niezrozumiałymi dla nich ,problemami szkolnymi”, podczas gdy problemy „rzeczywiście dla nich ważne” znajdują się - ich zdaniem - poza zasięgiem szkolnej edukacji (por. Cz. Kupisiewicz 1995).

Przy dzisiejszej szybkości poznawania, czyli tempie rozwoju nauki, nie sposób umieścić w programach choćby sygnalnie - ale zrozumiale dla ucznia -tego, nad czym pracują sztaby uczonych na całym świecie. Zawaliła się cała systematyka szkolna, czyli tradycyjny podział na przedmioty szkolne, albowiem istota wiedzy o świecie tkwi na pograniczach tradycyjnych dyscyplin akademickich.

Badania (por. Cz. Kupisiewicz 1995) potwierdziły, iż nasza szkoła końca XX wieku, to szkoła pamięci, realizuje bowiem te kategorie taksonomii celów kształcenia; przygotowuje bardziej do biernego gromadzenia informacji niż do samodzielnego myślenia, jest nastawiona na erudycję ogólną uczniów i myślenie „utartymi” i sprawdzonymi schematami niż na aktywne poszukiwanie nowych rozwiązań, nowej wiedzy.

Tę ocenę potwierdzili także inspektorzy OECD, którzy - w Raporcie na temat polityki edukacyjnej w Polsce (1995) - stwierdzili m.in., iż kształcenie ponadpodstawowe jest w Polsce nazbyt encyklopedyczne, niewystarczająco nastawione na przygotowanie twórczych i poszukujących umysłowości.

W programach szkolnych - stwierdzają autorzy Raportu - dominuje specjalizacja w poszczególnych dyscyplinach, a ponadto wiąże się z przestarzałym, zbyt wąskim podejściem do wiedzy poprzez frontalne nauczanie i nabywanie wiadomości drogą zapamiętywania (por. A. Bogaj 1997b, s. 100).

Nie jest to dla nas nowością, gdyż według B. Suchodolskiego (1958) - analizując umysłowe potrzeby dorastających i dorosłych - spostrzegamy wyraźny rozdźwięk między występującym wśród ludzi pragnieniem zrozumienia konkretnych problemów rzeczywistości a odpowiedziami, jakie mogą być przez nich znalezione w toku systematycznego studiowania wyspecjalizowanych dyscyplin naukowych. Ogromna większość problemów interesujących dziś ludzi ma charakter kompleksowy, to znaczy jest przedmiotem badań wielu różnych specjalistów. Natomiast nauczanie pozostaje wciąż działalnością podzieloną na treści interesujące nielicznych specjalistów.

Obrońcy takiego stanu rzeczy sądzą, iż najpierw należy opanować poszczególne gałęzie wiedzy w sposób izolowany od innych i w układzie ich wewnętrznej systematyki, aby dopiero na tej podstawie móc przystąpić do rozważania problemów kompleksowych z różnych punktów widzenia. Inny tok postępowania grozi - ich zdaniem - dyletantyzmem. Stanowisko takie nie jest jednak zupełnie przekonywujące. Przede wszystkim dlatego, iż w praktyce szkolnej nigdy nie dochodzi do drugiego etapu kompleksowego rozważania złożonych problemów i szkoła „wypuszcza” uczniów wyposażonych w pewne układy wiadomości według systematyki specjalistycznej, z którymi trudno coś począć, gdy pragnie się zrozumieć konkretne zjawiska. Taki typ nauczania, który ma zapewnić rzekomo lepiej, interesy wiedzy, w konsekwencji właściwie podcina zaufanie do niej. Wychodzący ze szkoły uczeń powinien nie tyle wiedzieć, jaki jest stan wiedzy w poszczególnych dyscyplinach, ale jak za pomocą zdobytej wiedzy można zrozumieć rzeczywistość (por. B. Suchodolski 1958, s. 5). 
Problemy, które powinny być w szkolnych programach rozpatrywane łącznie ze stanowiska różnych dyscyplin obejmują przede wszystkim niektóre zagadnienia kultury, techniki, higieny, życia społecznego, rozwoju psychicznego.

J. L. Lewis w czasie wystąpienia na Międzynarodowej Konferencji Wykształcenie przyrodnicze (Science) w krajach rozwijajacych się: od teorii do praktyki, która odbyła się 3-7 stycznia 1993 r. w Jerozolimie, powiedział: Reformy, które rozpoczęty się w późnych latach 50., prowadzity do zwiększenia liczby ćwiczeń laboratoryjnych wykonywanych samodzielnie przez uczniów. Uczniowie mieli aktywnie poznawać prawa fizyki, a nie dowiadywać się o nich od nauczyciela. Reformom tym brakowało jednak jednej rzeczy. Proponowane nauczanie nie potrafiło przedstawić takiego spojrzenia na nauki przyrodnicze, które dotyczytoby świata na zewnatrz klasy. Nauczany materiat nie zawierat społecznych, ekonomicznych $i$ środowiskowych aspektów nauk przyrodniczych oraz przykładów ich zastosowań (por. M. Głowacki 1994, s. 70).

Podobny kierunek zmian w procesie wykształcenia w zakresie nauk przyrodniczych został wytyczony przez uczestników Międzynarodowego Forum zorganizowanego przez UNESCO 5-10 lipca 1993 roku w Paryżu. Tematem Forum było: Wykształcenie naukowe i techniczne dla wszystkich - Projekt 2000+. W końcowej deklaracji Forum, w punkcie 1, jego uczestnicy piszą: Powotujac się na Światowa Deklaracje Wyksztatcenia dla Wszystkich, apelujemy o uznanie, że podstawowa wiedza $w$ dziedzinie nauki i techniki jest fundamentalna dla podniesienia poziomu nauki i techniki w świecie. Jednocześnie nawiąując do wyników Konferencji ONZ, dotyczacej rozwoju środowiska w Rio de Janeiro 3-14 czerwca 1992, apelujemy o szczególne zwrócenie uwagi na uwzględnienie problemów środowiska i życia ludzkiego (por. M. Głowacki 1994, s. 71).

\section{OPINIE NA TEMAT EFEKTYWNOŚCI KSZTALCENIA OGólNego W POLSCE}

Nie wszyscy podzielają jeszcze w pełni opinię o tym, że polska szkoła nie spełnia oczekiwań społecznych - jest dysfunkcjonalna. Niektórzy twierdzą (W. Paszyński 1995), że dzisiejsza szkoła spełnia te wymagania, że jej absolwenci radzą sobie zarówno w pracy, jak i w dalszym kształceniu. Popularna jest teza, że przeciętny polski maturzysta jest lepiej wykształcony (czy przynajmniej nie gorzej) od swojego zachodniego kolegi. Często mówi się, że powracający do swojej szkoły po zagranicznych wojażach uczniowie muszą powtarzać klasę, mimo że tam gdzie byli (USA, kraje skandynawskie, Europa Zachodnia) chodzili do szkół uchodzących za niezłe. To wszystko prawda, jak również i to, że coraz więcej pojawia się próśb o legalizację świadectw i dyplomów obcych szkół, najczęściej równoznaczną z uznaniem ich jako odpowiedników polskiej matury (przy czym tajemnicą poliszynela jest, iż posiadacze tych świadectw - mieliby kłopoty ze zdaniem egzaminu dojrzałości w kraju) (por. W. Paszyński 1995, s. 5).

Wyniki badań poświęconych temu zagadnieniu cytujemy za Andrzejem Bogajem: Mimo iż $w$ świetle wymagań programowych efektywność edukacyjna szkolnictwa ogólnoksztatcacego jest niska, to w porównaniu z innymi krajami wydaje się zadowalajaca, przynajmniej w zakresie przedmiotów przyrodniczych (fizyka, chemia, geografia, biologia). Potwierdzaja tę tezę wyniki osiagnięte przez uczniów polskich szkól ogólnokształcacych w ramach Drugiego Międzynarodowego Studium Przedmiotów Przyrodniczych (The Second International Science Study) realizowanego pod patronatem IEA (Międzynarodowe Stowarzyszenie Badania Osiagnięć Szkolnych), do którego Polska przystapiła w 1981 roku. Kierownikiem badań na terenie Polski byt Bolesław Niemierko (1988). Zgodnie z założeniami SISS/IEA badaniu poddano 3 populacje uczniów: 1) 10-letnich uczniów szkót podstawowych (kl. IV w Polsce),2) 14-letnich uczniów szkót podstawowych (kl. VIII w Polsce) i 3) uczniów kończacych szkotę średnią (klas maturalnych liceów ogólnokształcących dla niepracujacych $w$ Polsce). 
Wyniki uzyskane przez uczniów polskich w porównaniu z innymi krajami plasuja nasz kraj wśród 12 najlepszych. Uczniowie 10-letni uzyskali wyniki, które daty nam 11 miejsce na 24 kraje biorace udziat $w$ badaniach SISS. Znacznie lepsze rezultaty uzyskali 14-latkowie (7 miejsce), a najlepsze maturzyści liceów ogólnokształcąych (6 miejsce).

Jak wykazala jednak analiza ilościowo - jakościowa wyników osiagnięcia polskich 10-latków w zakresie przedmiotów przyrodniczych sq nieco niższe niż średnia dla wszystkich uczniów badanych $w$ tym wieku. Około 66\% szkót w Polsce uzyskało wynik (populacja 1) średni (około 52,2\% poprawnych odpowiedzi), tj. tyle, ile uzyskała najsłabsza szkoła w Japonii (por. K. Czupiat 1990, s. 96 i nast.). Ciekawe jest jednak to, iż dla dzieci 10-letnich w różnych krajach zadania sprawdzające wiedzę i umiejętności z poszczególnych kategorii celów ksztatcenia (wiadomości, rozumienie wiadomości, stosowanie wiadomości w sytuacjach typowych, stosowanie wiadomości w sytuacjach problemowych) nie byly jednakowo trudne. Dla dzieci w Polsce najłatwiejsze okazaty się zadania z najwyższych kategorii celów nauczania, co pozwoliło im wyprzedzić aż 8 krajów, podczas gdy w najniższych kategoriach celów gorsze wyniki uzyskaty tylko 3 kraje.

$W$ populacji uczniów 14-letnich wyniki dzieci polskich okazały się znacznie lepsze: tylko dziewięć krajów uzyskało wyniki wyższe, natomiast aż 15 krajów wyniki gorsze. Przy tej dość korzystnej dla naszych dzieci sytuacji trzeba podkreślić, iż bardziej zróżnicowany niż w innych krajach jest poziom naszych szkót podstawowych. Najbardziej jednorodne pod względem wyników nauczania $w$ grupie dzieci 14-letnich okazaty się szkoły w Norwegii, Japonii, Finlandii, Szwecji. Niestety szkoły w Polsce należa do grupy najbardziej zróżnicowanych obok: Holandii, Ghany, Filipin. Świadczy o tym fakt, iż aż 14\% szkót w Polsce nie osiagnęto wyniku najsłabszej szkoły węgierskiej (tj. 49,4\% poprawnych odpowiedzi). Najwięcej trudności sprawiła uczniom 14-letnim w Polsce - podobnie jak $w$ innych krajach - fizyka. Pod względem kategorii celów nauczania najłatwiejsze $w$ tej populacji okazały się zadania sprawdzajace rozumienie wiadomości (tu różnice między krajami byly najmniejsze). Największe zróżnicowania $w$ poziomie osiagnięć przyrodniczych uczniów wystapiły $w$ najwyższej kategorii celów (stosowanie wiadomości w sytuacjach problemowych).

Najlepiej wśród innych narodowości uplasowali się maturzyści liceów ogólnoksztatcacych w Polsce. Najwyższe wyniki w tej populacji uczniów uzyskały kraje, które stosuja duża selekcję uczniów do szkoły. Biorac pod uwage taksonomię celów nauczania przedmiotów przyrodniczych, stwierdzono, że Polska, obok Anglii, Ghany, Hongkongu, Węgier i Singapuru, należy do krajów o najlepszych wynikach w zapamiętanych wiadomościach, w zastosowaniu zaś wiedzy w sytuacjach typowych i problemowych przoduja maturzyści Australii, Kanady, Finlandii, Wtoch, Korei, Norwegii i Szwecji.

Na te dość dobre wyniki, świadczace o tym, że efektywność naszego szkolnictwa ogólnoksztatcacego jest porównywalna z efektywnościa szkolnictwa w krajach wysoko rozwiniętych, należy spojrzéc bardziej krytycznie i mniej optymistycznie, jeśli porównamy je z przeprowadzonymi ostatnio (1994/95) międzynarodowymi badaniami nad alfabetyzmem funkcjonalnym, w którym brała udział także Polska (A. Bogaj, 1997b, s. 98-100).

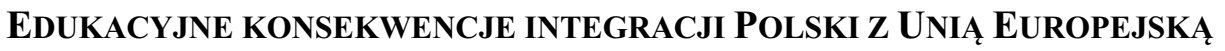

Z badań CBOS, prowadzonych w latach 1990-96, wynika że większość dorosłych Polaków popiera ideę integracji kraju z Unią Europejską (Komunikat CBOS, wrzesień 1996). Dążąc do pełnej integracji ze strukturami unijnymi musimy już teraz brać pod uwagę, reformując oświatę, między innymi takie czynniki, jak: kierunki zmian gospodarki rynkowej i edukacji w krajach wysoko rozwiniętych (wymagania jakościowe rynku pracy związane z szybkimi zmianami współczesnej techniki i technologii, bezrobocie wśród młodzieży; przemiany modeli życia społecznego; przemiany filozofii edukacji, nasilanie się w różnych krajach tempa upowszechniania kolejnych szczebli kształcenia oraz procesów migracyjnych, 
wreszcie wspólną w krajach UE politykę edukacyjną - przynajmniej w zakresie celów strategicznych itp. (por. A. Bogaj 1997a, s. 3).

Model systemu oświatowego ma ścisły związek z problemem zatrudnienia i perspektywami jego rozwoju w świecie. Obserwując i analizując dotychczasowe doświadczenia krajów rozwiniętych i perspektywy zatrudnienia można przypuszczać, iż trzeba myśleć o ograniczaniu kształcenia w zakresie nauk rolniczych oraz rozwoju kształcenia w zakresie usług. Według A. Karpińskiego (1996) najbardziej prawdopodobny scenariusz zmian w poziomie i strukturze zatrudnienia w Polsce w 2010 roku będzie następujący: zatrudnienie w rolnictwie $-20 \%$; w przemyśle przetwórczym $-17 \%$; w usługach rynkowych $-32 \%$; w usługach nierynkowych (edukacja, służba zdrowia, opieka socjalna) - 18\%. Zmiany zatrudnienia powinny być sygnałem dla systemu oświaty, w jakim kierunku powinno się przekształcać edukację zawodową (por. E. Drogosz-Zabłocka 1998, s. 66-71).

$\mathrm{Z}$ badań ekspertów OECD wynika, że przyszłość zatrudnienia uzależniona będzie od powstania nowych miejsc pracy wymagających wysokich kwalifikacji. Wszystkie badane kraje przewidują wzrost zatrudnienia specjalistów posiadających wysokie kwalifikacje, wśród których są: wyżsi urzędnicy, menedżerowie, specjaliści z zakresu nauk przyrodniczych i technicznych (tamże, s. 69).

Za Elżbietą Drogosz-Zabłocką cytujemy: W raporcie przygotowanym przez OECD (1994) na podstawie raportów z krajów członkowskich stwierdza się, że system oświaty oddzielajacy od siebie ksztatcenie ogólne od zawodowego, w którym nie wszystkie szkoły zawodowe daja możliwość kontynuowania nauki na poziomie uniwersyteckim, prowadzi nieodwotalnie do obniżenia pozycji szkół zawodowych. System ten nazwany przez autorów destylacja frakcyjna (schemat 1) przyczynia się już na starcie edukacji do pogtębiania selekcji szkolnych. W innym rozwiazaniu systemowym edukacja ogólna przeznaczona jest dla wszystkich, po niej dopiero wybiera się jeden z profili zawodowych. Taka postać przygotowania zawodowego stwarza każdemu uczniowi możliwość kontynuowania nauki na poziomie wyższym, przyczynia się też do lepszego przygotowania ksztatcenia ustawicznego. Drugie rozwiazanie (schemat 2), dające większe możliwości wyboru i awansu zawodowego przyrównywane jest do stynnego powiedzenia Napoleona Bonaparte: każdy żotnierz nosi w swoim plecaku buławe marszałkowska (E. Drogosz-Zabłocka, 1998, s. 64-65).

Rys. 2 Schematy zależności między kształceniem ogólnym i zawodowym

Destylacja frakcyjna

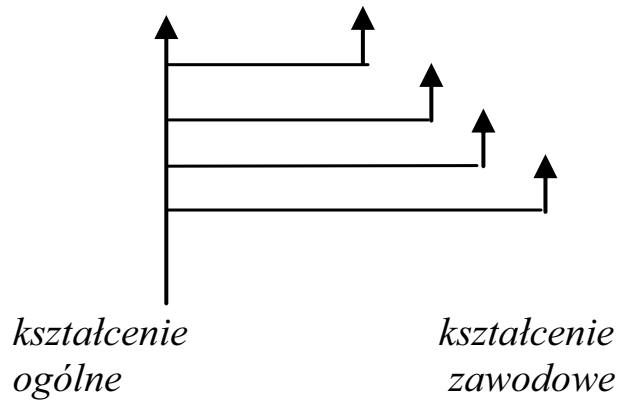

Każdy żotnierz może być
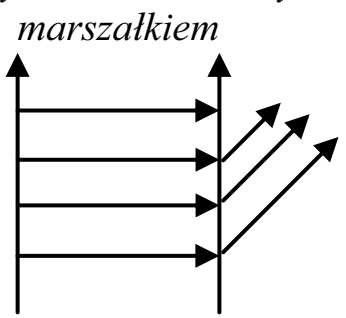

ksztatcenie profile ogólne zawodowe

Źródło: OECD, Le nouveau role de l'enseignement...,1994, s. 20

Eksperci podkreślają, że każde z państw członkowskich ma swoją drogę kształcenia zawodowego i różne są tam relacje między edukacją ogólną i zawodową. Zalecają więc, aby wybór systemu był dostosowany do warunków, możliwości i tradycji każdego z krajów (tamże, s. 66). 
Wspólne dla edukacji państw europejskich pozostaną jednak ogólnoludzkie wartości. Według K. Denka (1999, s. 62) dla krajów Unii Europejskiej wartościami są:

- Racjonalizm w sprawach doczesnych, odrzucenie wszelkiej ideologii pretendujacej do rozstrzygania o faktach za pomoca nienaukowych metod.

- Wolny i petny rozwój człowieka jako najwyższe dobro na ziemi i cel każdej polityki. Oznacza to, że spoleczeństwo istnieje dla jednostki, a nie tylko dla systemu.

- Wszyscy ludzie sa równi pod względem praw, nie ma „lepszych” ludzi, rodzin, narodów czy klas.

- Najlepiej chroni ustrój demokratyczny, wolność człowieka - choć też nie jest doskonala.

- Pluralizm w gospodarce, czyli wolny rynek, jako efektywniejszy od systemów ekonomicznych, zbudowanych w oparciu o monopol własności lub środków produkcji. Stanowiq one wspólne ideaty ,,dla wolnych ludzi”.

\section{LITERATURA}

Auleytner J., Wymagania nowego uczenia się człowieka a ksztatcenie nauczycieli, [w:] J. Gnitecki, J. Rutkowiak (red.): Pedagogika i edukacja wobec nadziei i zagrożeń współczesności. Warszawa-Poznań 1999.

Bogaj A., Kulturowe i cywilizacyjne determinanty reformy kształcenia ogólnego, [w:] J. Gnitecki, J. Rutkowiak (red.): Pedagogika i edukacja wobec nadziei i zagrożeń współczesności. Warszawa 1999.

Bogaj A. System edukacji w Polsce na tle porównawczym (próba analizy, [w:] Realia i perspektywy reform oświatowych. Warszawa 1997 (b).

Drogosz-Zabłocka E., Poszukiwanie relacji między przygotowaniem ogólnym a zawodowym, [w:] S. M. Kwiatkowski (red.): Nowe uwarunkowania edukacji szkolnej. Warszawa 1998.

Dziewulak D., Systemy szkolne Unii Europejskiej. Warszawa 1997.

Faure E. i in., Uczyć się aby być. Tłum. Z. Zakrzewska, A. Mońka-Stanikowa (red.). Warszawa 1975.

Głowacki M., Zainteresowania i potrzeby w nauczaniu i uczeniu się fizyki, [w:] W. Błasiak (red.): Jak zwiększyć zainteresowania uczniów fizyką. Dylematy nauczania fizyki. Tom I. Kraków 1994.

Jadczak M., Alfabetyzm funkcjonalny Polaków, [w:] „Nowe w Szkole”. nr 5/98-99.

Kupisiewicz Cz., Kanon wyksztatcenia ogólnego. Próba porównawczego zastosowania kierunków i dylematów przebudowy, [w:] A. Bogaj (red.): Kanon kształcenia ogólnego. Warszawa 1995. (a)

Kupisiewicz Cz., Kierunki przebudowy szkolnictwa w krajach uprzemysłowionych. „Kwartalnik Pedagogiczny" 1988, nr 3 / 4.

Kupisiewicz Cz., Paradygmaty i wizje reform oświatowych. Warszawa 1985.

Kwieciński Z., Edukacja wobec nadziei i zagrożeń współczesności, [w:] J. Gnitecki, J. Rutkowiak (red.): Pedagogika i edukacja wobec nadziei i zagrożeń współczesności. III Ogólnopolski Zjazd Pedagogiczny, Warszawa-Poznań 1999.

Mitter W., Formalna edukacja podstawowa w krajach uprzemystowionych. Analiza porównawcza w perspektywie XXI wieku. Referat wygłoszony na konferencji Education for all. Warszawa 1993.

Pachociński R., Oświata XXI wieku „Kierunki Przeobrażeń” Warszawa 1999.

Paszyński W., Sens i bezsens szkoły państwowej. „Nowa Szkoła” nr 4/1995.

Rabczuk W., Strategiczne cele edukacji w świetle raportu J. Delorsa i Białej Księgi Unii Europejskiej, [w:] A. Bogaj (red.): Realia i perspektywy reform oświatowych. Warszawa 1997. 
Suchodolski B., Nowoczesna treść i organizacja wykształcenia ogólnego. „Nowa Szkoła” $\mathrm{nr} 4 / 1958$

Wołoszyn S., Nauki o wychowaniu w Polsce w XX wieku. Próba zarysu encyklopedycznego. Warszawa 1997. 